\title{
The Growth in vitro of Killer Particles from Paramecium aurelia and the Axenic Culture of this Protozoon
}

\author{
By JILL WILLIAMS \\ School of Biological Sciences, University of East Anglia, Norwich, NOR 88C
}

(Accepted for publication I4 July I971)

SUMMAR Y

Paramecia belonging to certain strains of Paramecium aurelia (syngens I, 2 and 8) were transferred from dual culture with bacteria to axenic media, where the growth of some stocks continued, with weekly subculturing. The only axenically grown stock found to be capable of supporting growth of mu particles indefinitely was stock 138 (syngen 8).

Lambda and mu particles from axenically grown Paramecium aurelia were cultivated in vitro in a highly complex medium at $27^{\circ}$ under aerobic conditions. The particles retained their characteristic killing action on certain $P$. aurelia stocks but could not infect sensitive paramecia. The particles divided at approximately one fission per day and achieved a maximum density of only $\mathrm{I} 6-20 \times \mathrm{IO}^{3} / \mathrm{ml}$. The implications of these studies for the interaction of the nuclear genes and the killer particles are discussed.

\section{INTRODUCTION}

Symbiotic particles in the cytoplasm of Paramecium aurelia (Sonneborn, 1959; Beale, Jurand \& Preer, 1969) may enable the ciliate to kill other paramecia which lack particles. Electron microscope studies of the particles suggest that they are bacteria (Beale \& Jurand, I960; Beale et al. 1969; Jurand \& Preer, I969). They possess DNA, RNA, proteins, carbohydrates and lipids (van Wagtendonk \& Tanguay, I963; Smith-Sonneborn \& van Wagtendonk, I964; Stevenson, 1969). Mu particles contain diaminopimelic acid and possibly muramic acid which are characteristic of bacterial cell walls (Stevenson, 1967). The DNA content is similar in amount to that of free-living bacteria (Soldo, van Wagtendonk \& Godoy, I970; M. Chance, unpublished), ribosomal RNA is present (Baker, I970) and many key enzymes of metabolic pathways have been found (Kung, I968; J. Williams, unpublished). The kappa particles of stock 5 I have been shown to possess typical bacterial cytochromes (Kung, 1970). It might be anticipated, then, that these particles would grow outside the ciliate. Lambda particles (stock 299 , syngen 8 ) have been maintained in a highly complex medium but no characteristics of their growth cycle have been provided (van Wagtendonk, Clark \& Godoy, I963). In vivo they depend on host nuclear genes for their maintenance and replication (Preer, I968), each kind of particle requiring the presence of a specific nuclear gene or genes. Organisms with one copy of the nuclear gene possess approximately half the number of particles compared with those with two copies of the gene (Chao, I953; Balsley, 1966). The rate of replication of the particles is geared to that of the paramecium (Soldo, 1963).

The work reported here was concerned with the cultivation of the particles in various media outside the host organism and also with their maintenance within the host when the paramecia themselves were cultivated in axenic medium. 
METHODS

Strictly aseptic conditions were observed throughout.

Culture of paramecia in axenic media. Cultures of Paramecium aurelia are normally kept in grass medium containing Aerobacter aerogenes. Before attempting to cultivate the killer particles in vitro it was necessary to grow the paramecia without these bacteria. Transfer to axenic cultivation was carried out in one of two ways.

(a) Washing in sterile yeast extract: 100 to 200 paramecia from a dual culture with bacteria were washed through $0.25 \%$ yeast extract contained in five three-welled depression slides using a micropipette to transfer single organisms from well to well. The paramecia that remained alive at the end of this procedure were inoculated into $5 \mathrm{ml}$. axenic medium contained in test tubes, ro organisms per tube, and incubated at $27^{\circ}$, unless otherwise stated. (b) Antibiotic treatment: this method was not used for stocks bearing killer particles since the particles are sensitive to antibiotics. A small inoculum of paramecia was placed in $0.5 \mathrm{ml}$. axenic medium containing 0.07 to $0.05 \mathrm{ml}$. of a stock solution of $\mathrm{I} \times 10^{6}$ units of penicillin and $0.2 \mathrm{~g}$. streptomycin per $20 \mathrm{ml}$. in welled slides. When the swimming movements of the ciliates indicated that they had begun to be affected by the antibiotics, the remaining organisms were inoculated into $5 \mathrm{ml}$. axenic medium contained in test tubes, 10 organisms per tube, and incubated at $27^{\circ}$ unless otherwise stated.

Media used for the axenic cultivation of paramecia. The axenic medium was that of Soldo, Godoy \& van Wagtendonk (I966). This medium had a ratio of TEM-4T: (diacetyl tartaric acid esters obtained from tallow monoglycerides) stigmasterol of $100: 5 \mu \mathrm{g} . / \mathrm{ml}$. (" $100: 5$ ' axenic medium). In a series of experiments folic acid, one of the constitutents of this medium, was left out and attempts were made to grow killer and sensitive stock 299 animals in it. We also used axenic medium with a ratio of TEM-4T: stigmasterol of $40: 4 \mu \mathrm{g} . / \mathrm{ml}$. ('40:4' axenic medium). Other axenic media occasionally used were as follows. Medium A: this was the axenic medium of Soldo (1960) with many constituents, including Edamine $S$. However, the non-dialysable yeast fraction was replaced by TEM-4T, trypticase and yeast nucleic acid in the same concentrations as used in the '100:5' axenic medium (Soldo et al. 1966). Medium B: this was the same as medium A except that lactalbumin was used at a final concentration of $10.0 \mathrm{mg} . / \mathrm{ml}$. and replaced the Edamine $\mathrm{S}$.

Test for sterility of axenic cultures of paramecia, and of sterility of particle preparations. Axenic stocks and preparations of particles were checked for bacterial contamination in nutrient agar (Oxoid), nutrient broth (Oxoid), glucose-nutrient agar, glucose-nutrient broth, thioglycollate broth (Oxoid), Sabouraud broth (Oxoid), tryptone soya broth (Oxoid), axenic medium and axenic agar, i.e. axenic medium containing $\mathrm{I} \cdot 5$ to $2.0 \%$ agar. They were considered sterile if no growth appeared on any of the media at $27^{\circ}$ or $37^{\circ}$ after I4 days.

Maintenance of axenic stocks of paramecia. The axenic stocks were subcultured weekly by means of a $\mathrm{I} \mathrm{ml}$. inoculum of the 7 -day culture in $5 \mathrm{ml}$. of fresh medium, incubated at $20^{\circ}$ and $27^{\circ}$.

Isolation of particles from axenic paramecia. Stocks 299 and I38, containing lambda and $\mathrm{mu}$ particles respectively, and growing in axenic medium were the sources of the particles. $500 \mathrm{ml}$. paramecium culture were centrifuged at $600 \mathrm{~g}$ for $\mathrm{I} 0 \mathrm{~min}$. in an MSE oil-testing centrifuge, the pellet of paramecia homogenized by syringing with a hypodermic needle (2I-gauge $\times \mathrm{I} \frac{1}{2}$ in.) until no intact paramecia remained, and the homogenate then checked for sterility in the same way as the axenic stocks. The preparations of particles so obtained were inoculated into a wide variety of media and incubated at different temperatures. One ml. cultures of particles in vitro were subcultured every 4 to 5 days into $5 \mathrm{ml}$. medium. 
Media used for the cultivation of the particles. Medium C: this was the medium of van Wagtendonk et al. (I963) except that the non-dialysable yeast fraction was replaced by yeast RNA (B.D.H.) I mg. $/ \mathrm{ml}$., TEM-4T I00 $\mu \mathrm{g}$. $/ \mathrm{ml}$. and trypticase (BBL) $5 \mu \mathrm{g} . / \mathrm{ml}$. (Soldo et al. I966). Also the stigmasterol concentration was altered to $5 \mu \mathrm{g}$. $/ \mathrm{ml}$. Medium D: this was similar to medium $\mathrm{C}$ except that lactalbumin $0.5 \mathrm{mg} . / \mathrm{ml}$. replaced Edamine $\mathrm{S}$. Medium E: paramecia (either stock 562 with alpha particles, or stock 299 containing lambda particles, or stock 540 with mu particles) were cultured in bacterized media for 7 days at $27^{\circ}$ and this culture was used instead of distilled water to prepare nutrient agar, $\mathrm{pH} 77^{\circ}$. Medium F: stock 540 paramecia (without mu particles) were cultured at $27^{\circ}$ in ' $100: 5$ ' axenic medium for 7 days and then harvested aseptically. The pellet of organisms was broken by freezing and thawing once and then $8 \mathrm{ml}$. of this homogenate was added to $32 \mathrm{ml}$. of sterilized nutrient agar cooled to $40^{\circ}$, and plates were poured. The agar medium contained therefore sterile paramecium homogenate which had not been autoclaved. Sterility was tested by placing a sample plate at $27^{\circ}$. Medium G: this was PPLO broth (Difco) containing Bacto PPLO serum fraction (Difco) at a final concentration of $\mathrm{I} \%$.

Media used for growth of paramecia stocks and also particles. Medium $\mathrm{H}$ : this was a $\mathrm{I}$-day Aerobacter aerogenes culture in grass medium mixed with axenic medium (' $100: 5$ ') in ratios of $25: 27 ; 50: 50 ; 75: 25$. The $\mathrm{pH}$ was adjusted to $7 \cdot 0$ and the mixture autoclaved.

Counting methods used to estimate the number of particles $/ \mathrm{ml}$. in vitro. A sample of growth medium containing particles ( $5 \mathrm{ml}$. from test tubes, I 5 to $50 \mathrm{ml}$. from flasks) was filtered through a $0.45 \mu \mathrm{m}$. white plain millipore filter ( $24 \mathrm{~mm}$. diameter). The cells were resuspended in $0.5 \mathrm{ml}$. of filtered sterile distilled water plus $0.5 \mathrm{ml}$. latex suspension containing $10^{6}$ latex particles $/ \mathrm{ml}$. (DVB latex I $2 \cdot 0 \mu \mathrm{m}$. diameter, obtained from Coulter Electronics, Dunstable, Bedfordshire) mixed well on a whirlimix and placed in a haemocytometer (Hawksley, depth $0.2 \mathrm{~mm}$., area $\frac{-1}{400} \mathrm{~mm} .{ }^{2}$ ) and counted by the following methods under the microscope at a magnification of $\times 640$. The ratio of latex particles: killer particles was determined by counting 50 fields, and the number of particles $/ \mathrm{ml}$. in the original culture calculated. The number of organisms on the whole grid, i.e. $20 \times 20$ squares, were counted and the number/ml. calculated from this.

Test for in vitro growth of particles by their ability to kill sensitive paramecia. Paramecia containing killer particles are known to kill certain paramecia which do not possess the particles, e.g. stock 299 containing lambda releases a toxic substance into the medium which can kill stock 92 ; mu particles kill by a different method and require prolonged cell to cell contact such as occurs in mating.

Mu particles ( $0 \cdot 15 \mathrm{ml}$.) grown in vitro from stock 138 were added to ten ciliates of various paramecia stocks (stock 299 without lambda particles, stock 540 without mu particles, or stock 92) all contained in $0.5 \mathrm{ml}$. of ' $100: 5$ ' axenic medium. The mixtures were examined over a period of $60 \mathrm{~min}$. for the killing action of the particles.

Lambda particles $(0.15 \mathrm{ml}$.) growing in vitro from stock 299 were added to the same stocks in a similar way and observed over the same period of time.

In another experiment, $0.1 \mathrm{ml}$. lambda particles growing in vitro were added to $0.4 \mathrm{ml}$. sensitive stock 92 in bacterized culture in welled slides and left at room temperature. The mixtures were again examined over a period of $60 \mathrm{~min}$. for the typical behaviour of organisms that were being killed by toxic agents from lambda particles. 


\section{RESULTS}

Growth of particle-bearing and non-particle-bearing stocks in axenic medium. The results of growing paramecia with and without particles in axenic medium are shown in Table $\mathrm{I}$.

Stock I 38 without mu particles was obtained by growing stock I 38 containing mu particles at $32^{\circ}$ and subculturing every 3 to 4 days for approximately 28 days. Spontaneous loss of particles from stocks 299 and 562 occurred after growth of the paramecia in axenic medium. Stock I38, however, maintained its mu particles when grown in both ' $100: 5$ ' and '40:4' axenic medium at $20^{\circ}$ and $27^{\circ}$.

\section{Table 1. The growth of killer and sensitive paramecia in different axenic media}

Cells were removed from growth in bacterized culture by various techniques, and placed in different axenic media at different temperatures. They were examined to see if they grew and if they continued to contain killer particles.

\begin{tabular}{|c|c|c|c|c|c|c|c|}
\hline Stock & $\begin{array}{l}\text { Particles } \\
\text { present } \\
\text { in } \\
\text { original } \\
\text { culture }\end{array}$ & $\begin{array}{l}\text { Growth } \\
\text { in } \\
\text { axenic }\end{array}$ & $\begin{array}{l}\text { Ratio of } \\
\text { TEM-4T/ } \\
\text { stig- } \\
\text { masterol } \\
\text { in media } \\
\text { support- } \\
\text { ing } \\
\text { axenic } \\
\text { growth }\end{array}$ & $\begin{array}{l}\text { Method of } \\
\text { freeing } \\
\text { paramecium } \\
\text { from } \\
\text { bacteria }\end{array}$ & $\begin{array}{l}\text { Temp. } \\
\text { of } \\
\text { growth }\end{array}$ & $\begin{array}{l}\text { Maintenance } \\
\text { of particles } \\
\text { in axenic } \\
\text { paramecia }\end{array}$ & $\begin{array}{l}\text { Duration of } \\
\text { maintenance } \\
\text { of stocks }\end{array}$ \\
\hline 5 I3 (Syngen 1) & - & + & $100: 5$ & & & & Indefinitely in $\mathrm{I00:5}$ \\
\hline $60($ Syngen 1$)$ & - & + & $100: 5$ & Antibiotics & $27^{\circ}$ & No particles & Indefinitely in I00:5 \\
\hline 90 (Syngen 1$)$ & - & + & $100: 5$ & & & & Indefinitely in $100: 5$ \\
\hline 540 (Syngen I) & - & + & $100: 5$ & & & & $\begin{array}{l}\text { Maintained } \\
\text { indefinitely }\end{array}$ \\
\hline 540 (Syngen I) & $\mathrm{Mu}$ & - & $\left\{\begin{array}{r}100: 5 \\
40: 4\end{array}\right.$ & $\begin{array}{l}\text { Yeast extract } \\
\text { Antibiotics }\end{array}$ & $\left.\begin{array}{l}27^{\circ} \\
20^{\circ}\end{array}\right\}$ & $\begin{array}{l}\text { Cells never ob- } \\
\text { tained in axenic } \\
\text { medium }\end{array}$ & \\
\hline 562 (Syngen 2) & Alpha & + & $100: 5$ & $\begin{array}{l}\text { Derived from } \\
562 \text { with alpha }\end{array}$ & $\left\{\begin{array}{l}27^{\circ} \\
20^{\circ}\end{array}\right.$ & No particles & $\begin{array}{l}\text { Maintained in- } \\
\text { definitely in axenic } \\
\text { medium }\end{array}$ \\
\hline I 14 (Syngen 2) & Sigma & - & $100: 5$ & Yeast extract & $\left\{\begin{array}{l}27^{\circ} \\
20^{\circ}\end{array}\right.$ & $\begin{array}{l}\text { Cells never ob- } \\
\text { tained in axenic } \\
\text { medium }\end{array}$ & \\
\hline 138 (Syngen 8) & $\mathrm{Mu}$ & + & $\left.\begin{array}{c}100: 5 \\
40: 4 \\
100: 10\end{array}\right\}$ & Yeast extract & $\left\{\begin{array}{l}27^{\circ} \\
20^{\circ}\end{array}\right.$ & $\begin{array}{l}\text { Maintained in- } \\
\text { definitely in two } \\
\text { media at both } \\
\text { temperatures (i.e. } \\
100: 5,40: 4)\end{array}$ & $\begin{array}{l}\text { Maintained in- } \\
\text { definitely }\end{array}$ \\
\hline I38 (Syngen 8) & - & + & $\left.\begin{array}{r}100: 5 \\
40: 4\end{array}\right\}$ & $\begin{array}{l}\text { Derived from } \\
\text { I } 38 \text { killers }\end{array}$ & $\left\{\begin{array}{l}27^{\circ} \\
20^{\circ}\end{array}\right.$ & No particles & $\begin{array}{l}\text { Maintained in- } \\
\text { definitely }\end{array}$ \\
\hline 299 (Syngen 2) & Lambda & + & $100: 5$ & $\begin{array}{l}\text { Washing in } \\
\text { yeast extract }\end{array}$ & $\left\{\begin{array}{l}27^{\circ} \\
20^{\circ}\end{array}\right.$ & $\begin{array}{l}\text { Lambda main- } \\
\text { tained for } 5 \\
\text { weeks, i.e. approx. } \\
100 \text { fissions at } \\
20^{\circ} \text { and } 27^{\circ}\end{array}$ & $\begin{array}{l}\text { After loss of lambda } \\
\text { particles, sensitive } \\
\text { stock was main- } \\
\text { tained indefinitely }\end{array}$ \\
\hline 299 (Syngen 8) & - & + & $100: 5$ & $\begin{array}{l}\text { Derived from } \\
299 \text { killers }\end{array}$ & $\left\{\begin{array}{l}27^{\circ} \\
20^{\circ}\end{array}\right.$ & No particles & $\begin{array}{l}\text { Maintained in- } \\
\text { definitely }\end{array}$ \\
\hline
\end{tabular}

Stock I 4 containing sigma could not be grown in axenic medium. Many attempts were made to grow stock 540 mate killers (containing mu particles) in a wide variety of axenic media (including media A and B) and under different conditions. The only media used which 
gave partial success were $50 \%$ axenic ' $100: 5$ ' medium in which the ciliates lived for I 9 days at $27^{\circ}$, and 50:50;25:75;72:25 medium $\mathrm{H}$ in which the paramecia lived for 6 to 7 days, but on subculturing they did not grow and eventually died. In all other media, e.g. ' $100: 5$ ' axenic medium, they died within 3 to 4 days.

Stock 299 cells without lambda particles and stock 138 without mu particles have also been grown in medium A without folic acid for 12 weekly subcultures.
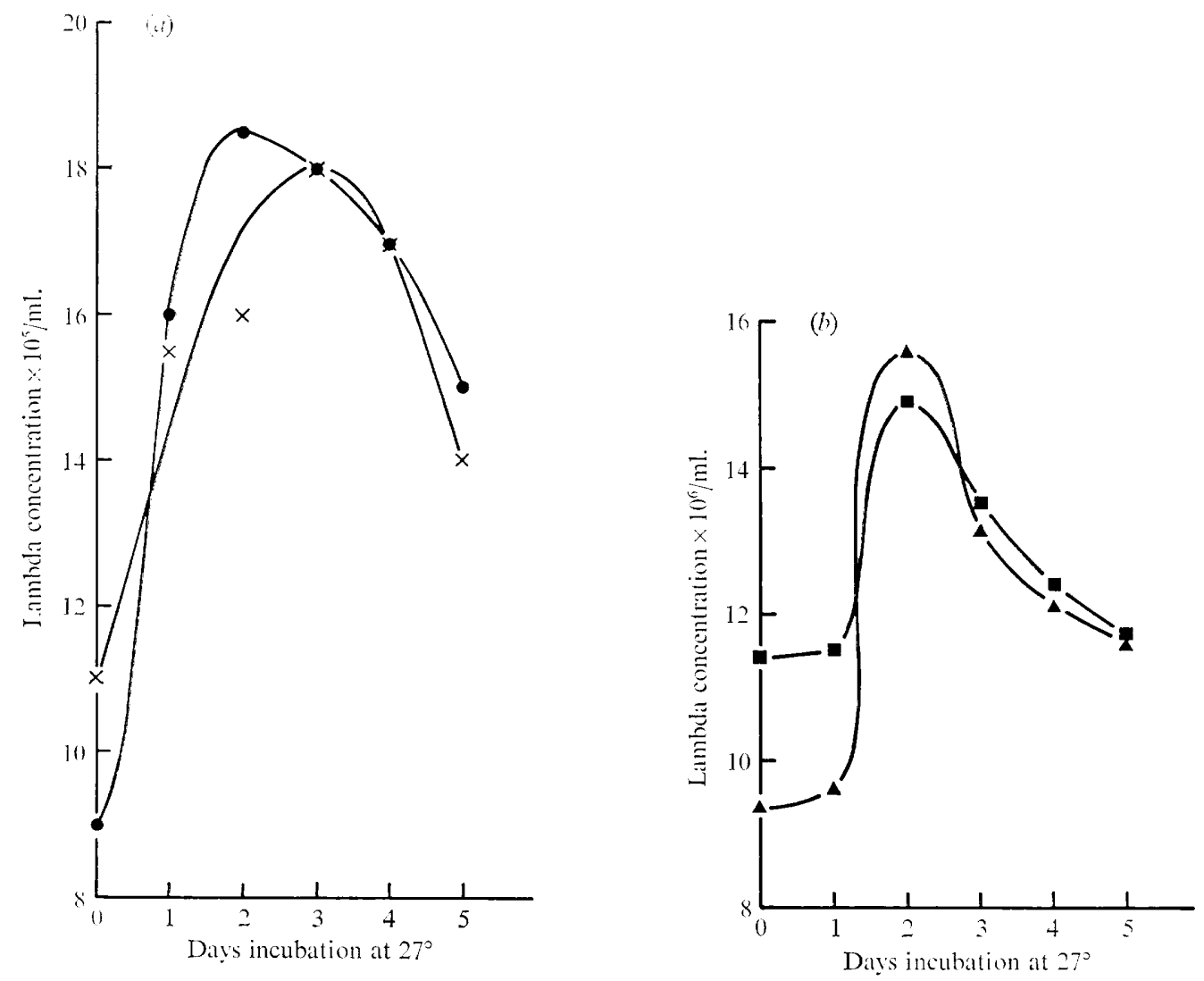

Fig. I. (a) Doubling effect with lambda particles in media G and D at inoculum sizes of $9 \times 10^{5}$ and I $\times 10^{5}$ particles $/ \mathrm{ml}$. 9 , Growth in medium $\mathrm{G} ; \times$, growth in medium D. $(b)$ Doubling effect with lambda particles in media $\mathrm{C}$ and $\mathrm{G}$ at inoculum sizes of $9.4 \times 10^{6}$ and $1 \mathrm{I} \cdot 4 \times 10^{6}$ particles $/ \mathrm{ml}$.

Growth in medium C; $\boldsymbol{\Delta}$, growth in medium $\mathrm{G}$.

In vitro growth of particles. On inoculation of lambda and mu particles immediately after isolation from paramecia as described in Methods the particles underwent 'the doubling effect', i.e. approximately doubled their numbers. This phenomenon was observed in all the bacteriological media tested regardless of inoculum size. The media used for these experiments included C, D and G, ' $100: 5$ ' axenic medium and nutrient broth. The cultures were incubated aerobically at $27^{\circ}$. The results are plotted in Figs. I $(a)$ and $(b)$ for lambda particles in media G, C and D. The initial concentration of lambda particles on inoculation into, for instance, medium $\mathrm{G}$ was $9 \times 10^{5}$ in Fig. I $(a)$ and $9.4 \times 10^{6}$ in Fig. I $(b)$. After the approximate doubling, the particles rapidly fell in number.

In all the media tested, except media $\mathrm{C}, \mathrm{D}$ and $\mathrm{G}$, the particles on continued subculturing did not undergo further fissions and disappeared (i.e. in nutrient broth, ' $100: 5$ ' axenic 
medium and all the other bacteriological media the particles only divided once immediately after isolation from the paramecia). In media C, D and G, however, on further subculturing when the inoculum size was below $20 \times 10^{3} / \mathrm{ml}$., both lambda and mu particles divided and were maintained by subculturing for 6 months as described in Methods. I have called this the 'growth effect'.

The inoculum size of lambda particles from stock 299 (that had undergone the 'doubling effect') in medium $C$ was varied so that the initial concentration was $\mathrm{I} \times \mathrm{IO}^{3} / \mathrm{ml}$., $3 \times \mathrm{IO}^{3} / \mathrm{ml}$., $4.5 \times 10^{3} / \mathrm{ml}$. or $6 \times \mathrm{IO}^{3} / \mathrm{ml}$, and after 4 days incubation at $27^{\circ}$ the lambda particles reached a concentration of $\mathrm{I} 6$ to $20 \times \mathrm{IO}^{3} / \mathrm{ml}$, , then decreased rapidly. Similarly, following inoculation

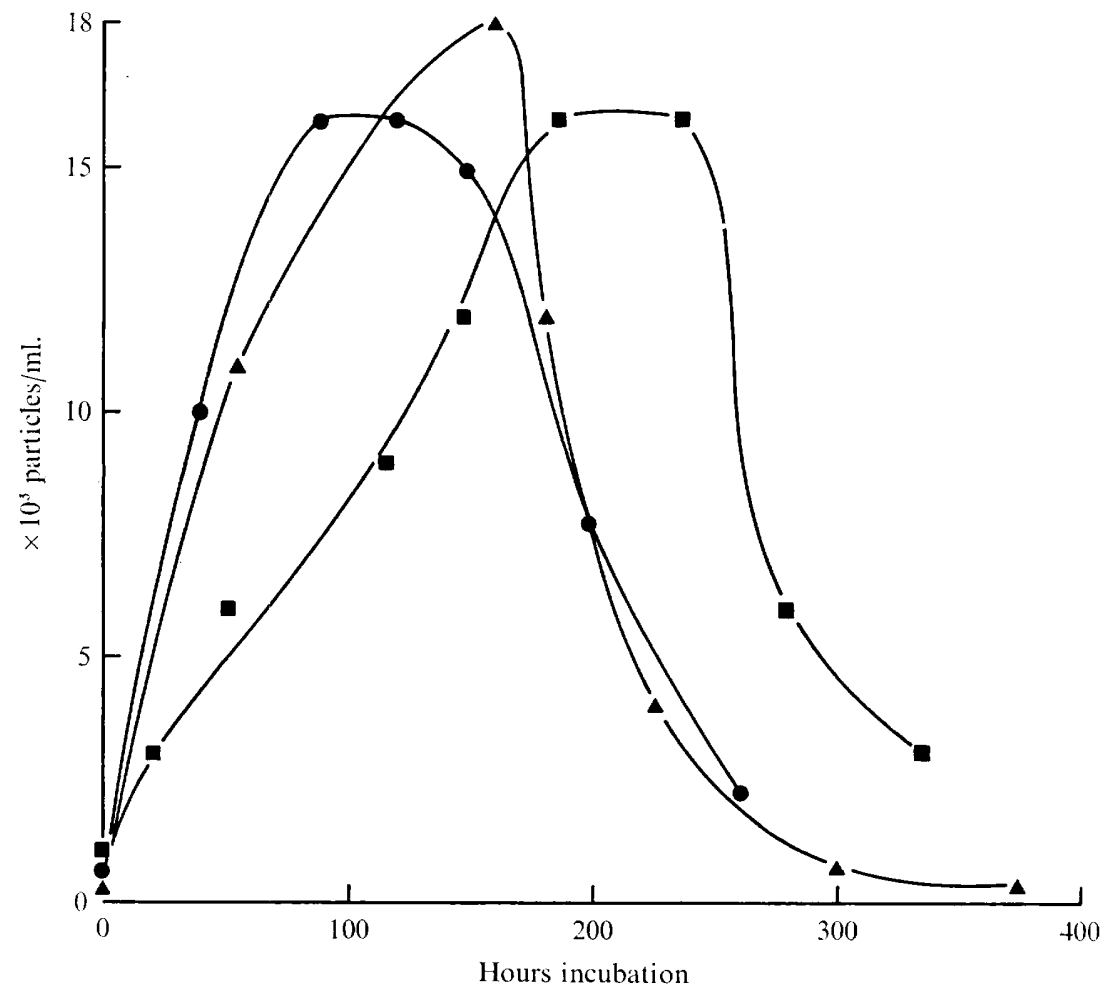

Fig. 2. Growth of lambda in medium $C$ and mu particles in media $\mathbf{G}$ and $\mathrm{C}$. $\mathbf{\square}$, Lambda growth in $500 \mathrm{ml}$. medium $\mathrm{C}$ contained in a Thompson bottle at $27^{\circ}$ under aerobic conditions; $\mathrm{O}$, mu growth in $300 \mathrm{ml}$. medium $\mathrm{G}$ contained in a $500 \mathrm{ml}$. Erlenmeyer flask at $27^{\circ}$ under aerobic conditions; $\boldsymbol{\Delta}$, $\mathrm{mu}$ growth in $300 \mathrm{ml}$. medium C contained in a $500 \mathrm{ml}$. Erlenmeyer flask, in shaking aerobic culture at $32^{\circ}$.

of mu particles from stock 138 at initial concentrations of $6 \times 10^{2} / \mathrm{ml} ., 4 \times 10^{3} / \mathrm{ml}$. or $6 \times 10^{3} / \mathrm{ml}$, the particles grew until they reached $\mathrm{I} 6$ to $20 \times \mathrm{IO}^{3} / \mathrm{ml}$. before the numbers fell rapidly. This decrease was not due to a change in $\mathrm{pH}$. The fission rate has been studied in this growth period and is shown in Fig. 2 for lambda and mu particles. Mu particle growth is shown in media $\mathrm{G}$ and $\mathrm{C}$, while lambda growth is shown in medium $\mathrm{C}$ only. Both particles divided approximately once per day and the number of fissions depended on the initial inoculum size. The maximum concentration the particles achieved in vitro was 16 to $20 \times 10^{3} / \mathrm{ml}$.

No success in increasing the maximum density or growth rate of lambda or mu particles in vitro was obtained by adding homogenates of paramecia to the media, by renewing the growth media, or by adding additional nutrients such as L-cysteine, L-glutamine, 'Marmite', 
nicotinamide adenine dinucleotide, ATP and KCP. Lambda and mu particles did not grow in medium $\mathrm{G}$ containing crystal violet (Difco) which selects for mycoplasmas and inhibits all bacterial growth.

Killing experiments with in vitro grown particles. Since the particles when present in paramecium confer killer properties on the organism, proof that the particles we have been observing are indeed the killer particles would be to show that they can kill certain sensitive stocks of paramecium.

Two different experiments were prepared to test for the killing action of lambda particles grown in vitro. A I-day lambda culture (0.15 ml.) in medium C (i.e. 16 to $20 \times 10^{3}$ lambda/ ml.) was mixed with ten paramecia, none of which contained particles, of each of the following stocks: 92 (syngen 3), 540 (syngen I), 299 (syngen 8), all contained in $0.5 \mathrm{ml}$. medium. After 10 min. all ten of the stock 92 organisms were dead. The ten stock 540 paramecia were alive for $60 \mathrm{~min}$. but with stock 299 , five organisms were killed in $60 \mathrm{~min}$. In the control wells, with paramecia contained in $0.5 \mathrm{ml}$. axenic medium, the ciliates remained alive for 60 min. Paramecium aurelia stock 299 containing lambda killed stock 92 and stock 299 without particles but not stock 540 .

In the second experiment a 4-day culture of lambda in medium $\mathrm{C}$ was used. In the control, i.e. stock 92 alone in bacterized medium, the paramecia were alive after $60 \mathrm{~min}$., and in the second control, i.e. stock $92+$ medium $\mathrm{C}$ without lambda particles, the paramecia were alive after $\mathrm{I} 5 \mathrm{~min}$. In the experimental well, i.e. $0.4 \mathrm{ml}$. stock $92+0 \cdot 1 \mathrm{ml}$. lambda in medium $\mathrm{C}$ after $5 \mathrm{~min}$. the paramecia began to swim in an odd fashion typical of lambda killing, and within $5 \mathrm{~min}$. all the organisms were dead.

To study the killing action of $\mathrm{mu}$ in vitro, $0.15 \mathrm{ml}$. of $\mathrm{mu}$ from an in vitro culture in medium $\mathrm{C}$ was used, i.e. 15 to $20 \times 10^{3} \mathrm{mu} / \mathrm{ml}$, , and mixed with Io paramecia of each of the three same stocks, in the same way as for the first lambda killing experiment above. With stock 299 all the organisms were dead within $30 \mathrm{~min}$; however, with stocks 92 and 540 all the paramecia were alive after 60 min. Paramecium aurelia stock 138 containing mu particles killed certain sensitive stocks in syngen 8 but not stocks in other syngens as it was a mate killer.

Infection experiments with in vitro grown particles. Various attempts to infect stock 299 lacking lambda particles with the in vitro grown lambda were unsuccessful. On the other hand, particles prepared from paramecia growing in axenic medium were found to infect stock 299 sensitives. This was done by adding a serial dilution of a homogenate of stock 299 grown axenically and containing lambda to a bacterized culture stock 299 without lambda contained in welled slides at room temperature. The wells were topped up every day with fresh bacterized medium, examined over a period of Io days, and scored for infection. Infection was first observed after approximately 2 days. Attempts to infect stock I 38 without mu particles with the in vitro grown mu were also unsuccessful. These results seem to indicate either that the infective ability of the particles is altered during the in vitro growth, or that the conditions of the infection experiment are not the same for in vivo and in vitro particles.

\section{DISCUSSION}

The most interesting feature of the symbionts which occur in the nucleus and cytoplasm of Paramecium aurelia is that morphologically and biochemically they resemble bacteria. Lambda can be grown in vitro (van Wagtendonk et al. I963) and the present work has shown that $\mathrm{mu}$ and lambda can grow outside the host ciliate.

The particles would grow in vitro to a concentration of 16 to $20 \times 10^{3} / \mathrm{ml}$. and when inside 
a paramecium the maximum concentration of the particles was approximately $2 \cdot 7 \times 10^{9} / \mathrm{ml}$, i.e.

$$
\begin{array}{ll}
\text { Vol. of a paramecium }=3.75 \times 10^{-7} \mathrm{ml} . & \begin{array}{l}
\text { (paramecium considered as a cuboid } \\
\text { with a square base of side } 50 \mu \mathrm{m} . \text { and } \\
\text { height } \mathrm{I} 50 \mu \mathrm{m} .)
\end{array} \\
\text { Particles/organism }=10^{3} &
\end{array}
$$

$\therefore$ Concentration of particles $=2 \cdot 7 \times \mathrm{IO}^{9} / \mathrm{ml}$. in cytoplasm of organism.

This indicates three possibilities. First, the gene was obviously not necessary for limited growth outside the ciliate and possibly the gene protects the particles from destruction by the paramecium; secondly the nuclear gene might have influenced the number and/or the fission rate of the particles, thus affecting the density of the particles present in the cell. Thirdly the optimum medium for particle growth has not yet been found and there is no fundamental reason why the particles cannot grow to numbers approaching $2.7 \times 10^{9}$ in vitro.

The low fission rate may be an adaptation to a symbiotic mode of life because the paramecium divides approximately once every $8 \mathrm{~h}$. If the particles multiplied at the rate of Escherichia coli (approximately one fission every $24 \mathrm{~min}$.) the host would soon become overpopulated.

The doubling effect was observed only when the particles were first isolated from the host paramecium and was probably caused by the particles completing a division that had begun in the host cell. This is analogous to the division of chloroplasts on first isolation from plants (Ridley \& Leech, 1970). If the particles were allowed to divide and complete the doubling effect and were then inoculated at high concentrations, i.e. above $20 \times \mathrm{ro}^{3} / \mathrm{ml}$., into fresh medium, this doubling effect was not observed and they disappeared rapidly until the numbers reached $16-20 \times 10^{3} / \mathrm{ml}$. This effect may also be observed for Escherichia coli with inocula above maximum concentration.

Another approach to the problem of particle maintenance was to grow the paramecia themselves in axenic medium, since it is known from enzyme studies that the host physiology is different in axenic medium from bacterized medium (Rowe, Gibson \& Cavill, 197I). Only with stock 138 killers were the mu particles found to be maintained indefinitely and this raises the question of why the other particles, for example alpha and lambda are less easily maintained in axenic medium than bacterized medium. The particles can also be maintained in other protozoa (Sonneborn, 1965; Gibson, 1965).

Previously it has been reported that ' $100: 5$ ' axenic medium supported the growth of particle bearers in the even but not the odd numbered syngens of Paramecium aurelia (Soldo et al. 1966) and that the TEM-4T:stigmasterol ratio was important in the maintenance of stocks. Stock I 38 (syngen 8) containing mu particles, however, has been maintained in the present work in axenic medium with weekly subculturing at both $27^{\circ}$ and $20^{\circ}$ for I 2 weeks in TEM-4T: stigmasterol ratios of 100:5, 40:4 and 100: 10 without loss of particles in any of the media. After this period the paramecia growing in 100:10 medium began to die although particles were present up to death. The paramecia in the 100:5 and 40:4 medium remained healthy and so it would seem that not only the ratio of TEM-4T: stigmasterol but also the final concentration is important in maintenance of the stock as the cells lived in 40:4 but died in 100: 10 axenic medium.

Soldo et al. (1966) observed that axenic medium (100:5) supports the growth of the even but not the odd number syngens of Paramecium aurelia with the exception of stock 92 (syngen 3 ). In the same paper Soldo reported that stock 299 containing lambda was supported indefinitely. 
It has been shown above that syngen I stocks"5I3,60, 90 and 540 (without particles) are maintained indefinitely in this medium. In roo:5 axenic medium stock 299 containing lambda were maintained for only 5 weeks at $20^{\circ}$ and $27^{\circ}$, after which period the paramecia lost their particles. It is reported that stock 540 with mu particles will grow and maintain the particles in 40:4 medium (van Wagtendonk, Goldman \& Smith, I970). However, I have not been able to repeat this. In the same paper van Wagtendonk et al. claim to have maintained mu particles in stocks 548 and $55^{I}$ of syngen $I$ in $40: 4$ medium. They also disclose that strains within a syngen respond differently to ' $40: 4$ ' and ' $100: 5$ ' media. This is at variance with my observations.

Soldo (1963) claimed that while both stock 299 containing lambda particles and stock 299 without lambda particles grew in the complete axenic medium, only the particle-bearing stock grew in axenic medium without folic acid. The sensitive stock died. He concluded from these experiments that the lambda particles provided the host paramecium with folic acid. I have not been able to demonstrate this. In my experiments stock 299 without lambda and stock 138 without mu survived at least 12 weekly subcultures into $100: 5$ axenic medium without folic acid.

From the growth of the particles in vitro it seems reasonable to envisage the particles as bacteria or of bacterial origin. They may represent a stage in evolution between a free-living bacterium and an obligate parasite as they can live in the paramecium and grow in vitro (although with a low fission rate and to a low maximum density) with a growth curve typical of most bacteria. It would be interesting to study the growth of other particles outside the host paramecium since there may be different degrees of integration in terms of replication rate and mechanism of maintenance involved with different particles.

This work was carried out while the author was a recipient of a Science Research Council Scholarship. Thanks are due to Dr Ian Gibson who supervised this work.

\section{REFERENCES}

BAKER, R. (1970). Studies on the RNA of the mate-killer particles of Paramecium. Heredity 25, 657-662.

BALSLEY, M. (1966). Dependence of the kappa particles of stock 7 of Paramecium aurelia on a single gene. Genetics 54, 320-325.

Beale, G. H. \& Jurand, A. (I960). Structure of the mate-killer (mu) particles in Paramecium aurelia, stock 540. Journal of General Microbiology 23, 243-252.

Beale, G. H., Jurand, A. \& Preer, J. R. (1969). The classes of endosymbiont of Paramecium aurelia. Journal of Cell Science 5, 65-9I.

Chao, P. K. (1953). Kappa concentrations per cell in relation to the life cycle, genotype and mating type in Paramecium aurelia, variety 4. Proceedings of the National Academy of Sciences of the United States of America 39, 103-I13.

GiBson, I. (1965). The replication of metagons and mu particles from Paramecium in another cellDidinium. Genetical Research 6, 398-410.

Jurand, A. \& Preer, L. B. (1969). Ultrastructure of flagellated lambda symbionts in Paramecium aurelia. Journal of General Microbiology 54, 359-364.

KUNG, C. (1968). Oxidative metabolism of kappa particles from Paramecium aurelia stock 5 i in relation to their nature and origin. Ph.D. Thesis, University of Pennsylvania.

Kung, C. (1970). The electron transport system of kappa particles from Paramecium aurelia stock 51. Journal of General Microbiology 6r, 371-378.

Preer, J. R. (1968). Genetics of the protozoa. In Research in Protozoology, vol. 3, pp. I39-288. Edited by T. Chen. Oxford: Pergamon Press.

RidLEy, S. M. \& LEECH, R. M. (1970). Division of chloroplasts in an artificial environment. Nature, London 227, $463-465$. 
Rowe, E. A., Gibson, I., \& Cavill, A. (197I). The effects of growth conditions on the esterases of Paramecium aurelia. Biochemical Genetics 5, 15 I-I59.

Smith-Sonneborn, J. E. \& Van Wagtendonk, W. J. (1964). Purification and chemical characterization of kappa of stock 5I, Paramecium aurelia. Experimental Cell Research 33, 50-59.

Soldo, A. T. (1960). Cultivation of two strains of killer Paramecium aurelia in axenic medium. Proceedings of the Society for Experimental Biology and Medicine, ro5, 6I 2-6I5.

Soldo, A. T. (1963). Axenic culture of Paramecium-some observation on the growth behaviour and nutritional requirements of a particle bearing strain of Paramecium aurelia 299. Annals of the New York Academy of Sciences 108, 380-388.

Soldo, A. T., Godoy, G. A. \& Van Wagtendonk, W. J. (I966). Growth of particle-bearing and particle-free Paramecium aurelia in axenic culture. Journal of Protozoology 13, 492-497.

Soldo, A. T., van Wagtendonk, W. J. \& Godoy, G. A. (1970). Nucleic acid and protein content of purified endosymbiont particles of Paramecium aurelia. Biochemica et biophysica acta 204, 325-333.

SonNeborn, T. M. (1959). Kappa and related particles in Paramecium. Advances in Virus Research 6, $229-356$.

SoNNEBORN, T. M. (1965). The metagon, RNA and cytoplasmic inheritance. American Naturalist 99, $279-307$.

Stevenson, I. (1967). Diaminopimelic acid in the mu particles of Paramecium aurelia. Nature, London 215, 434-435.

Stevenson, I. (1969). The biochemical status of mu particles in Paramecium aurelia. Journal of General Microbiology 57, 6I-75.

van Wagtendonk, W. J., Clark, J. A. D. \& Godoy, G. A. (I963). The biological status of lambda and related particles in Paramecium aurelia. Proceedings of the National Academy of Sciences of the United States of America 50, 835-838.

van Wagtendonk, W. J., Goldman, P. H. \& Smith, W. L. (1970). The axenic culture of strains of the various syngens of Paramecium aurelia. Journal of Protozoology 17, 389-39I.

van Wagtendonk, W. J. \& Tanguay, R. B. (I963). The chemical composition of lambda in Paramecium aurelia, stock 299. Journal of General Microbiology 33, 395-400. 